\title{
Risk of human health by particulate matter as a source of air pollution -Comparison with tobacco smoking-
}

\author{
Makoto Enomoto', William J. Tierney² and Kohsuke Nozaki ${ }^{3}$ \\ ${ }^{1}$ JAMSEA Medical Corps (NPO), 2-9-22 Shinjuku, Shinjuku-ku, Tokyo 160-0022, Japan \\ ${ }^{2}$ Tierney and Associates, 687 County Road 579, Pittstown, NJ 08867, USA \\ ${ }^{3}$ KOKEN Ltd., Head Office, 7 Yonbancho, Chiyoda-ku, Tokyo 102-0081, Japan
}

(Received December 18, 2007)

\begin{abstract}
Increased air pollution, containing carcinogenic particulate matter smaller than $2.5 \mu \mathrm{m}$ $\left(\mathrm{PM}_{2.5}\right)$, has gained particular attention in recent years as a causative factor in the increased incidence of respiratory diseases, including lung cancer. Extensive carcinogenicity studies conducted recently under Good Laboratory Practice conditions by National Toxicology Program in the USA, Ramazzini Foundation in Italy or Contract Research Organizations on numerous chemical compounds have demonstrated the importance of considering dose levels, times and duration of exposure in the safety evaluation of carcinogenic as well as classical toxic agents. Data on exposure levels to chemical carcinogens that produce tumor development have contributed to the evaluation of human carcinogens from extrapolation of animal data. A popular held misconception is that the risk from smoking is the result of inhaling assorted particulate matter and by products from burning tobacco rather than the very low ng levels of carcinogens present in smoke. Consider the fact that a piece of toasted bread contains ng levels of the carcinogen urethane (ethyl carbamate). Yet, no one has considered toast to be a human carcinogen. Future human carcinogenic risk assessment should emphasize consideration of inhalation exposure to higher levels of benzo (a) pyrene and other possible carcinogens and particulate matter present in polluted air derived from automobile exhaust, pitch and coal tar on paved roads and asbestos, in addition to other environmental contaminant exposure via the food and drinking water.
\end{abstract}

Key words: Air pollution, Particulate matter, Tobacco smoking, Exposure dose level, Carcinogenesis, Lung cancer

\section{INTRODUCTION}

As R. A. Weinberg described in his book; "Racing to the Beginning of the Road (1996)", the incidence of lung cancer increased dramatically over the past two centuries. It became most prevalent as occupational cancers in late 18th century Europe during the industrial revolution from the use of coal for heating (Clayson, 1962; Hueper and Conway, 1964; Arcos et al., 1968). Similar occupational cancers of the skin and urinary bladder were also evident in industrial workers and miners. Unlike these relatively new forms of cancer, resulting from environmental contamination, there are no indications that the worldwide incidence of other forms of cancer have increased. In addition, there is no clear epidemiological evidence that lung cancer was the result of smoking tobacco in the American Indian or native New Guinea populations.

In addition to Weinberg, M. Enomoto, observed lung cancer was a rare finding at St. Luke's International Hospital, Tokyo and the University of Tokyo Hospital, Tokyo, where he worked as a human pathologist from 1954 to 1961 (Matsui, 1960; Kitagawa, 1965). During the early 1970 's, dramatic increase in lung cancers were evident in the urban areas of Japan similar to that seen in the United State during the late 1940's. The incidence of lung cancer in Japanese males is the most prevalent form of cancer in Japan since 1995, exceeding that of stomach cancer (Fig. 1). A similar trend was evident fifty years earlier in the United States from 1940 to 1950 (Fig. 2).

Sir Percivall Pott observed that many patients that had

Correspondence: Makoto Enomoto (E-mail: enomotom@y2.dion.ne.jp) 


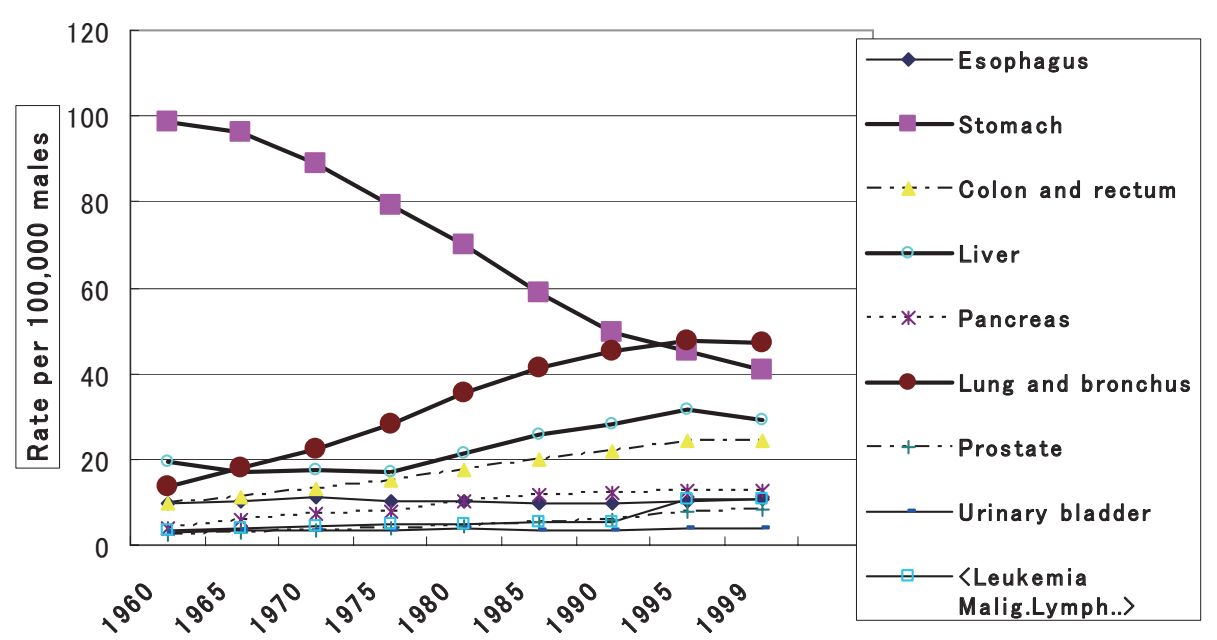

Fig. 1. Age-adjusted cancer death rate among males for selected cancer types, Japan, 1960-1999.

Compiled from the data of "Kokumin-eisei no Doukou (Current Japanese Health)", (2001), Health Welfare Statitistics, 48, 416.

cancer of the scrotum were "chimney sweeps" in late eighteenth century. Malignant skin tumors (epitheliomas) were experimentally produced by painting coal tar onto the ears of rabbits by Yamagiwa and Ichikawa in 1918. Interestingly enough, the coal tar used was imported from France and not the tar from burning tobacco leaves (Yamagiwa and Ichikawa, 1918). Since that time carcinogenicity studies using animal models coupled with human epidemiological evidence, comparison of threshold dos-

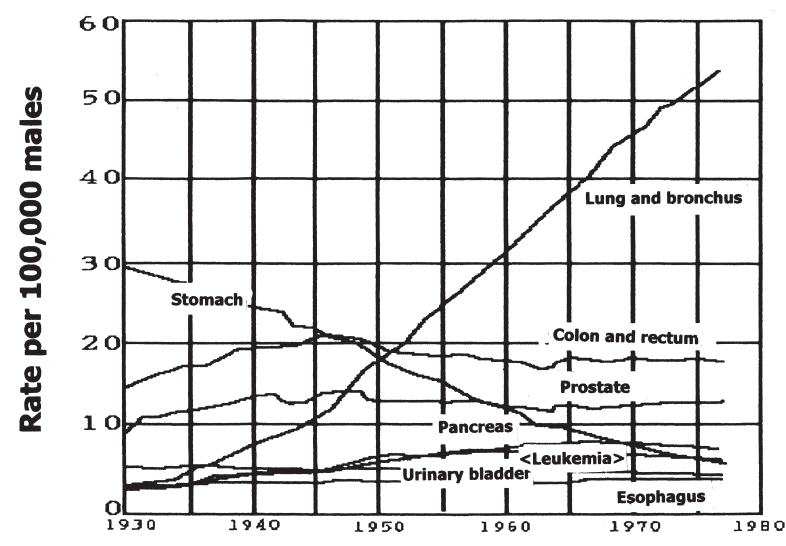

Fig. 2. Age-adjusted cancer death rate among males for selected cancer types, USA, 1930-1977.

Elias, P.S. (1990): Food safety issues; The EEC approach. In: Abstract. on international conference on issues in food safety and technology, pp.13-14, Augt. 29, 1990 Mich. St. Univ., East Lansing, Mich. es and historical data have been used to identify unknown carcinogens (Enomoto, 2000).

The little known fact that cigarette smoke contains carcinogenic aromatic hydrocarbons or nitrosamines; 60 to 200 ng/one cigarette (IARC, 1990) or benzo (a) pyrene; 12.9 to $19.9 \mathrm{ng} /$ cigarette (Nozaki and Kawai, 1978), respectively, comparable to the content of the carcinogen urethane in a piece of whole wheat toast, $312 \mathrm{ng}$ (Zimmerli and Schlatter, 1991) has not been taken into consideration. Such levels are so low they are considered to possess negligible carcinogenic potential and not a risk to humans (Enomoto, 2000; Williams et al., 2004). The classical coal stove produces 1.7 to $3.3 \mathrm{~g}$ (per BTU: British thermal units; $0.2520 \mathrm{Kcal}$.) of benzo (a) pyrene, more than million times of that in tobacco smoke. It should be remembered that coal is the natural decomposition product of plants over millions of years under high pressure and temperature. Indoor air pollution from burning coal was reported to be closely related to the high incidences of lung cancer in Xuan Wei, China, particularly in women who did the cooking (Mumford et al., 1987). Japanese were also exposed to pollution of burning "Rentan", made from powdered coal for cooking, for approximately twenty years including years of World War II. In addition, an increased incidence of lung cancer, with deposits of particulate matter, was evident in dogs living in large cities from 1962 to 1966 (Takemoto et al., 1968). Churg et al. (2003) suggested that chronic exposure to high levels of ambient particulate matter (mean levels of $\mathrm{PM}_{2.5}$; $22 \mu \mathrm{g} / \mathrm{m}^{3}$ ) is associated with small airway remodeling of 
Air pollution and tobacco smoking

human lungs.

Modern lifestyles in industrial cities, including automobile use and exposure to exhausts from coal and petroleum greatly contribute to the accumulation of particulate matter in the atmosphere (Handa et al., 1983; Matsusita, 1989; Valberg and Crouch, 1999; Lena et al., 2002; Churg et al., 2003). Atmospheric reactions of sunlight with hydrocarbons and automobile exhausts and other particular matter produces an oxidizing, photochemical type of air pollution. Level of atmosphere contamination can reach levels that are hazardous to man and the environment. Aldehydes are the major products in the photo-oxidation of hydrocarbons and in the reactions of hydrocarbons with ozone, oxygen atoms as free radicals. Formaldehyde and acrolein are present in urban atmospheres. Approximately, 50\% of the total aldehyde is present as formaldehyde (Menzel and Amdur, 1996). In addition, road pavement contains asphalt (Nozaki, 1988) and produces particulate matter containing residual oil fly ash and many kinds of metals (Hunt et al., 2003). Carcinogens were previously reported to be present in the air of major cities and industrial sites at a level of $\mu \mathrm{g}$ or greater/ $\mathrm{m}^{3}$ (Table 1). The cause and effect of increased incidences of respiratory cancers resulting from air pollution is clearly evident.

One consideration why smokers have a higher incidence of respiratory disease than non-smokers may be that smokers orally inhale the burnt tobacco smoke directly into the lungs bypassing the filtering effects of the nose and nasal cavities on airborne pollutants. However, much of $\mathrm{PM}_{2.5}$ in polluted air undergoes peroxidation due to burning tobacco while smoking (Fig. 3). Can moderate smoking be enjoyed safely in a clean environment.

The purpose of this review is to emphasize the importance of exposure levels of toxic and carcinogenic substances present as particulate matter in air pollution. Emphasis must be placed on effects of chemicals on environmental contamination in our modern society and their effects on the development of human disease, especially respiratory diseases (Lewtas et al., 1983; Cupitt and Fitz-Simmons, 1988; Mastrangela, 1996; Woodruff et al., 1998; Moyer et al., 2002; Suwa, et al., 2002; Liu et al., 2003).

\section{Significance of exposure level of carcinogens}

\section{A. Animal data}

Analyses of the carcinogenic potency database accumulated by NTP in the USA (Huff et al., 1988; Ashby and Tennant, 1991; Huff, 1999) and Ramazzini Foundation in Italy (Soffritti et al., 2002), and of carcinogenicity studies on industrial chemicals including pharmaceuticals and pesticides conducted at worldwide GLP facilities (Enomoto et al., 1996) have supported refined risk assessments based on the evaluation of state-of-the art scientific evidence coupled with sound epidemiology studies and not speculation. Recent studies on mechanisms of carcinogenesis by both genotoxic and non-genotoxic carcin-

Table 1. Air pollution: Measurement data of particulate matter $\left(\mathrm{PM}_{2.5}\right)$ and benzo (a) pyrene

\begin{tabular}{|c|c|}
\hline Contents & Air Pollution \\
\hline Particulate matter: & Average ambient concentration: 4.9-19.2 $\mu \mathrm{g} / \mathrm{m}^{3}, \mathrm{USA}^{1)}$ \\
\hline \multirow[t]{3}{*}{$\mathrm{PM}_{2.5}$} & Airborne PM conc.: 19.0-29.9 $\mu \mathrm{g} / \mathrm{m}^{3}$, Urban areas ${ }^{2)}$ \\
\hline & $120-960 \mu \mathrm{g} / \mathrm{m}^{3}:$ Air planes, taverns, workrooms ${ }^{3)}$ \\
\hline & Particulate emissions: Diesel vehicle $0.23 \mathrm{~g} / \mathrm{km}$, Gasoline vehicle $0.021 \mathrm{~g} / \mathrm{km}$ ) \\
\hline \multirow[t]{6}{*}{ Benzo (a) pyrene } & 1.7-3.3 g/BTU*: Coal stove ${ }^{5)}$ \\
\hline & $9.6 \pm 2.6 \mu \mathrm{g} / \mathrm{m}^{3}$ in traffic tunnels $\left.{ }^{6}\right)$ \\
\hline & Tar stuck on gasoline engine mufflers: $139 \mu \mathrm{g} / \mathrm{g}$ 7) \\
\hline & 2.6-7.4 ng/m3; Room for smokers $1.1-4.4 \mathrm{ng} / \mathrm{m}^{3}$ : Non-smoking room. ${ }^{5)}$ \\
\hline & 20-40 ng: Main stream smoke/cigarette ${ }^{8)}$ \\
\hline & $<*$ BTU: British thermal units; 0.2520 Kcal.> \\
\hline
\end{tabular}

Ref.: 1) Schwatz et al., 2002; 2) Lena et al., 2002; 3) Cupitt and Fitz-Simmons, 1988; 4) Strandell et al., 1994; 5) Matsushita, 1989; 6) De Fré et al., 1994; 7) Handa et al., 1983; 8) Nozaki, 1966; Nozaki and Kawai, 1978 


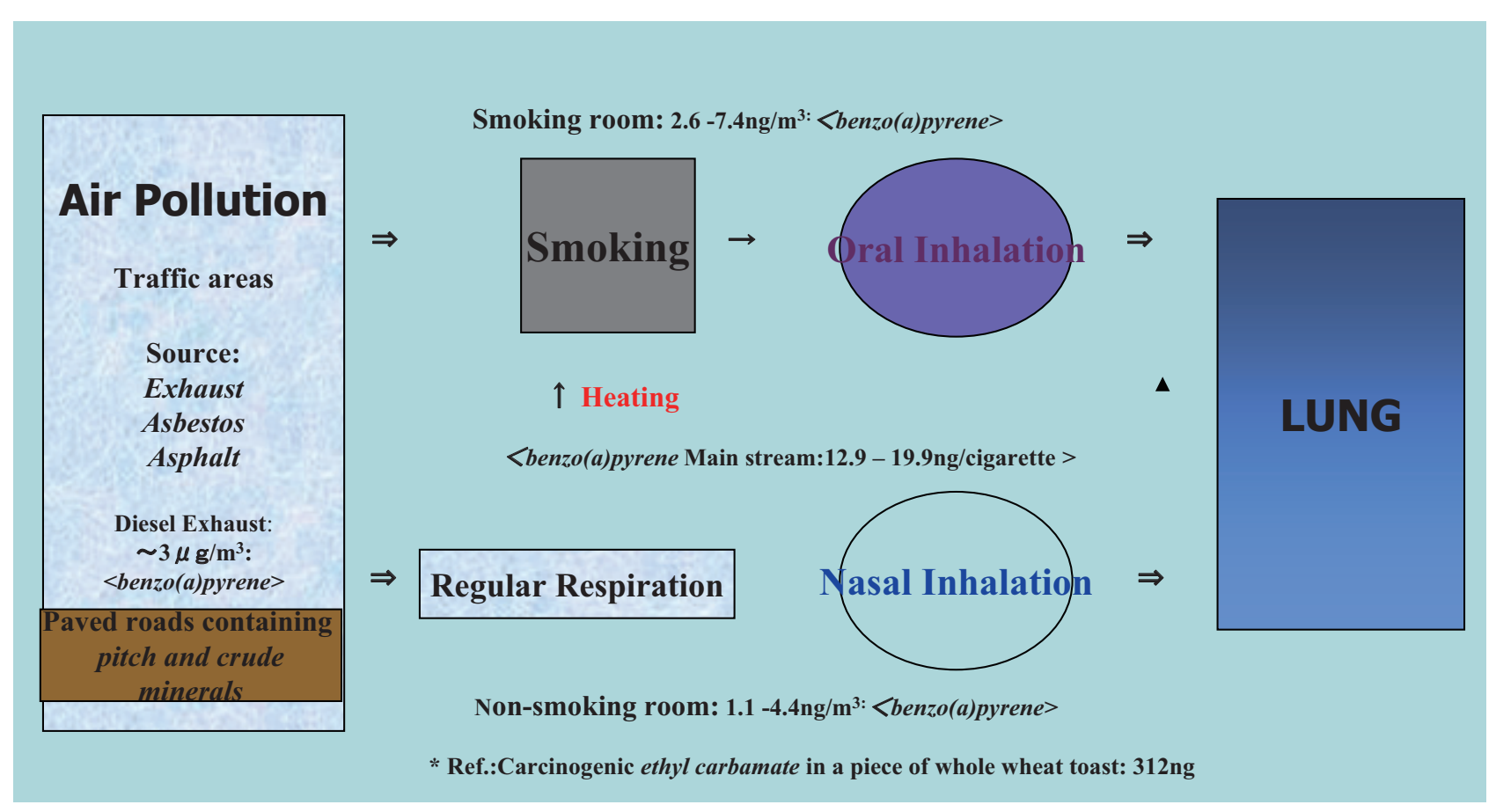

Fig. 3. Air pollution and tobacco smoking.

Ref. (Sakabe et al., 1965; Nozaki, 1966; Nozaki and Kawai, 1978; Matsushita, 1989; Zimmerli and Schlatter, 1991)

ogens conducted in parallel with long-term studies have also supported the more relevant evaluation of carcinogenesis data obtained after two years of feeding, inhalation, or other routes of exposure (Tennant, 1993; Gold et al., 1998; Kundsen, 1999; Ward, 2007).

Improved animal study facilities and design, including sufficient number of treatment groups, consisting of three or more study dose levels with sufficient numbers of animals per group in conjunction with gross and histological evaluations of all tissues, lesions and masses led to more meaningful data for realistic interpretations (Maronpot, 1985). Analysis of the results of recently completed carcinogenicity studies revealed for the first time the existence of dose-levels which had no apparent, treatment-related effects on carcinogenic processes and the concept of threshold doses (Enomoto et al., 1990; Enomoto, 2000). Toxicological pathologists have evaluated numerous histological specimens from all organs of animals (Roe, 1972). In addition, they have become aware of "whole body carcinogenesis" as dose-depended and time-related responses, in view of recent elucidation of the effects of defense mechanisms, including DNA replication and repair, oxidative stress, hormonal influences and cytokines on homeostasis (O'connor et al., 2000; Enomoto, 2000; Cook and Calabrese, 2006). A number of more sophisticated mechanistic studies including formation of DNA adducts (Williams et al, 2000), GST-P positive foci and 8-OHdG formation (Fukushima et al, 2002) are suggestive of no risk of cancer to humans at low levels of environmental exposure to DNA-reactive carcinogens. The finding of no-effect levels provides a basis for understanding why very low level environmental exposures of humans, even to DNA-reactive carcinogens, may not be cancer risks (Williams, 2004).

The number of dose groups and dose levels are critical to determine safe dose levels. However, the maximum dose levels as stipulated in regulatory guidelines may result in manifestation of specific biological effects due to unrealistic overdose, saturating adaptation or hormesis exceeding body-burden effects (Calabrese and Baldwin, 2003). Consequently, many of the chemicals evaluated resulted in positive toxic or carcinogenic responses, probably due to oxidative effects including those caused by lack of drug metabolizing enzymes. Using the maximum tolerated dose (MTD) as the highest dose in carcinogenicity studies provoked debate in the classical safety evaluation of chemicals (Haseman and Seilkop, 1992; Hengstler et al., 2003). Most studies that showed positive carcinogenic responses at the MTD, not statistically or biologically significant, were non-genotoxic car- 


\section{Air pollution and tobacco smoking}

cinogens, and therefore are not relevant as a real human carcinogenic threat (Lewis et al., 1998; Huff, 1999; Ward, 2007). Recent data, including hormonal, nutritional and age-associated metabolic changes that can influence the occurrence of naturally-occurring tumors have contributed to evaluation of long-term bioassay data, which show an increase or decrease in the incidence of these tumors in the rat or mouse (Enomoto et al., 1990). Large granular lymphocytic (LGL) leukemia or chronic nephropathyrelated renal cancer seen predominantly at high dose-levels near the MTD in Fischer 344 rats seems to be due to promotion and not direct effects.

Similar to the results of extensive studies on more than a hundred chemicals conducted by NTP (Huff et al., 1988), approximately $40 \%$ of non-genotoxic chemicals evaluated in both rats and mice at the Biosafety Research Center (An-Pyo), Japan, showed positive neoplastic responses in one or more of the sex-species experiments, from 1983 to 1999 (Enomoto et al., 1996). Whereas three genotoxic chemicals were positive in all four groups, non-genotoxic compounds exhibited species or sex-related responses to tumor development. In addition, nearly all chemicals examined were negative at low and mid-dose levels in all studies of both genotoxic and non-genotoxic chemicals.

Table 2 shows the ratio of the highest or middle dose capable of inducing tumor development to the lowest or middle dose that did not induce tumors. Since the highest dose level was selected based on the MTD, $10 \%$ reduction in body weight, the ratio was analyzed against the mid-dose, when mid-dose was capable of inducing tumor development. Generally, this ratio was less than a hundred fold, and generally less than ten with pharmaceuticals. Only two pharmaceuticals tested were positive in one sex/species at the low dose level. The reason is unclear. Table 3 lists chemicals with positive neoplastic responses selected from the NTP database, from 1983 to 1999 (Fung et al., 1995; Huff, 1999). For carcinogenicity studies using only two dose levels, both dose groups showed the same positive or negative neoplastic responses occasionally. Similar results were also seen in studies employing three dose levels, when the ratio between low and high dose levels was less than ten (four or five). The Biosafety Research Cernter used a ratio of ten as a generally employed safety factor for carcinogenicity studies on pharmaceuticals. All databases on exposure levels obtained from extensive carcinogenicity studies appear to suggest that carcinogenic doses generally lie in the range between maximum and the minimum levels of doses required to induce tumors (Enomoto et al., 1996).

Results of the studies listed above revealed that the ratio of the highest dose capable or inducing tumor development to the lowest dose that did not induce tumor development was generally less than a hundred-fold. Only a few strong carcinogens such as aflatoxin $\mathrm{B}_{1}$ and some nitroso-compounds exhibited a wider range, between 100 to 1,000 fold (Enomoto, 2000).

\section{B. Human exposure and cancer}

Many occupational carcinogens were well known in the past, and were due to the lack of safety procedures for workers (Hueper and Conway, 1964). Some pharmaceutical products, especially anti-neoplastic and immuno-suppressive agents, can cause cancer, when used at high therapeutic dose levels (Dedrick and Morrison, 1992; Fraser, 1996).

Since most chemical carcinogens exhibit their potential to induce tumors at dose levels in the order of one microgram $(\mu \mathrm{g})$ per kilogram of body weight per day or greater, cancer development would not be expected at exposure levels less than 100 parts per billion (ppb), corresponding to $2.5 \mu \mathrm{g} / \mathrm{kg}$ body weight per day in humans (Enomoto, 2000). Williams et al. have suggested that food-borne carcinogens would not be carcinogenic at a level of less than $1.5 \mathrm{mg} /$ person/day. Even the strongest carcinogen, $\mathrm{AfB}_{1}$ may be not oncogenic at a level of less than $30 \mathrm{ppb}$, approximately $45 \mu \mathrm{g} /$ person/day by this assumption (Williams et al., 2004).

In parallel with the extensive research on PM health effects advocated by US Environmental Protection Agency (Lippmann et al., 2003), a number of epicemiologic and biomedical studie have shown that hazardrous air pollutants may pose a potential public health threat for the past 50 years. Recent worldwide efforts in this field have resulted in the accumulation of data on air pollutants including carbon, and $\mathrm{PM}_{10}$ or $\mathrm{PM}_{2.5}$ containing polycyclic aromatic hydrocarbons derived from diesel and gasoline exhausts (Cupittet et al., 1988; Strandell et al., 1994; Mastrangelo et al., 1996; Woodruff et al., 1998; Lena et al., 2002).

Human risk assessment of complex mixtures of polycyclic organic matter (POM) employs an evaluation of comparative potency for estimating human cancer risks when no data exists for the POM being assessed, but does for similar POM mixtures. Such cancer risk estimations are expressed as $1 \mu \mathrm{g} \mathrm{POM} / \mathrm{m}^{3}$ of inhaled air (Lewtas, 1993). Diesel emissions and cigarette smoke were the POM emission sources evaluated for comparison to those from coke ovens or roofing coal tar using the comparative potency method. As illustrated in Fig. 6 of their manuscript, risks of cigarette smoke appear to be less than 1/100 compared to POM estimates of other three 
M. Enomoto et al.

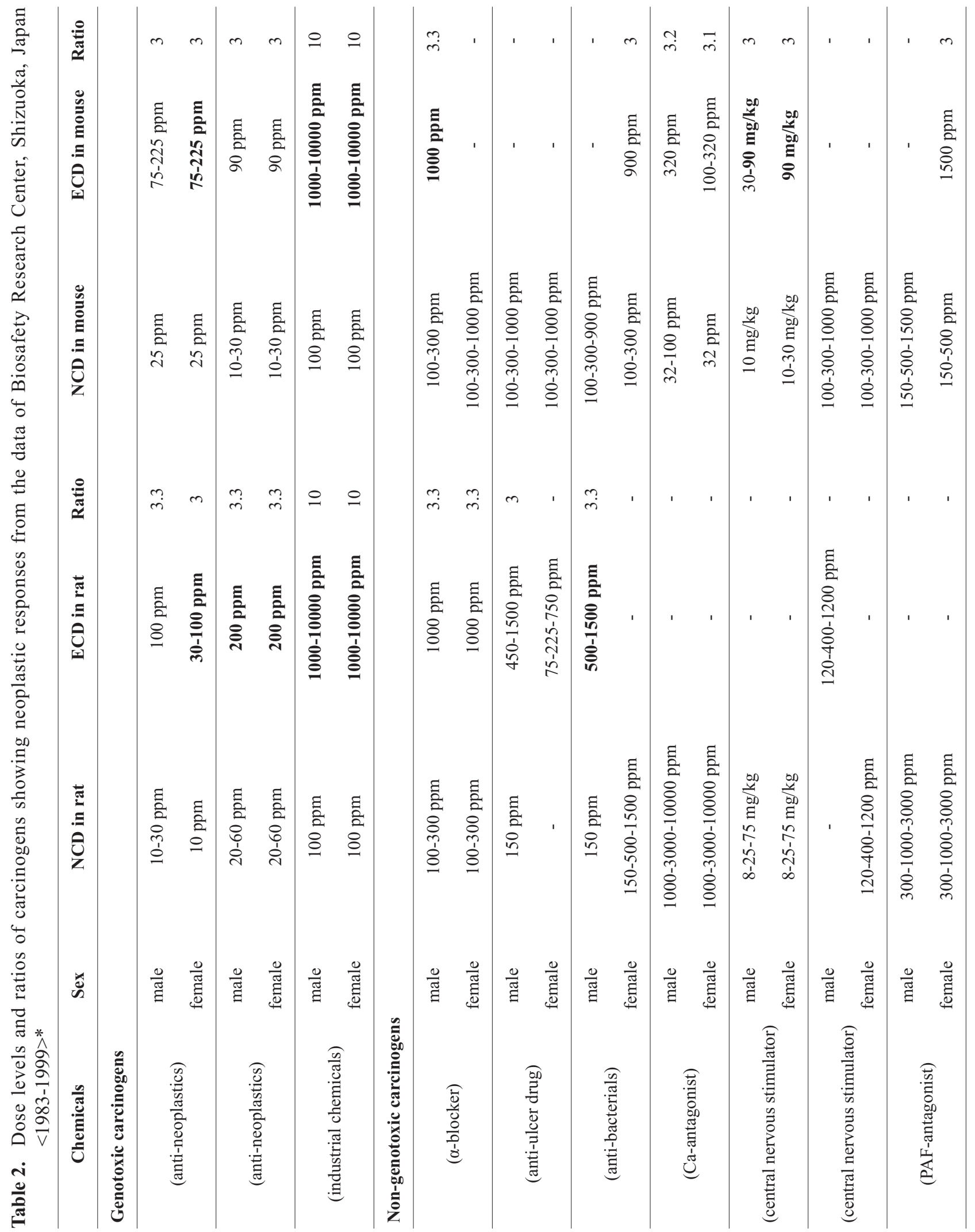

Vol. 33 No. 3 
Air pollution and tobacco smoking

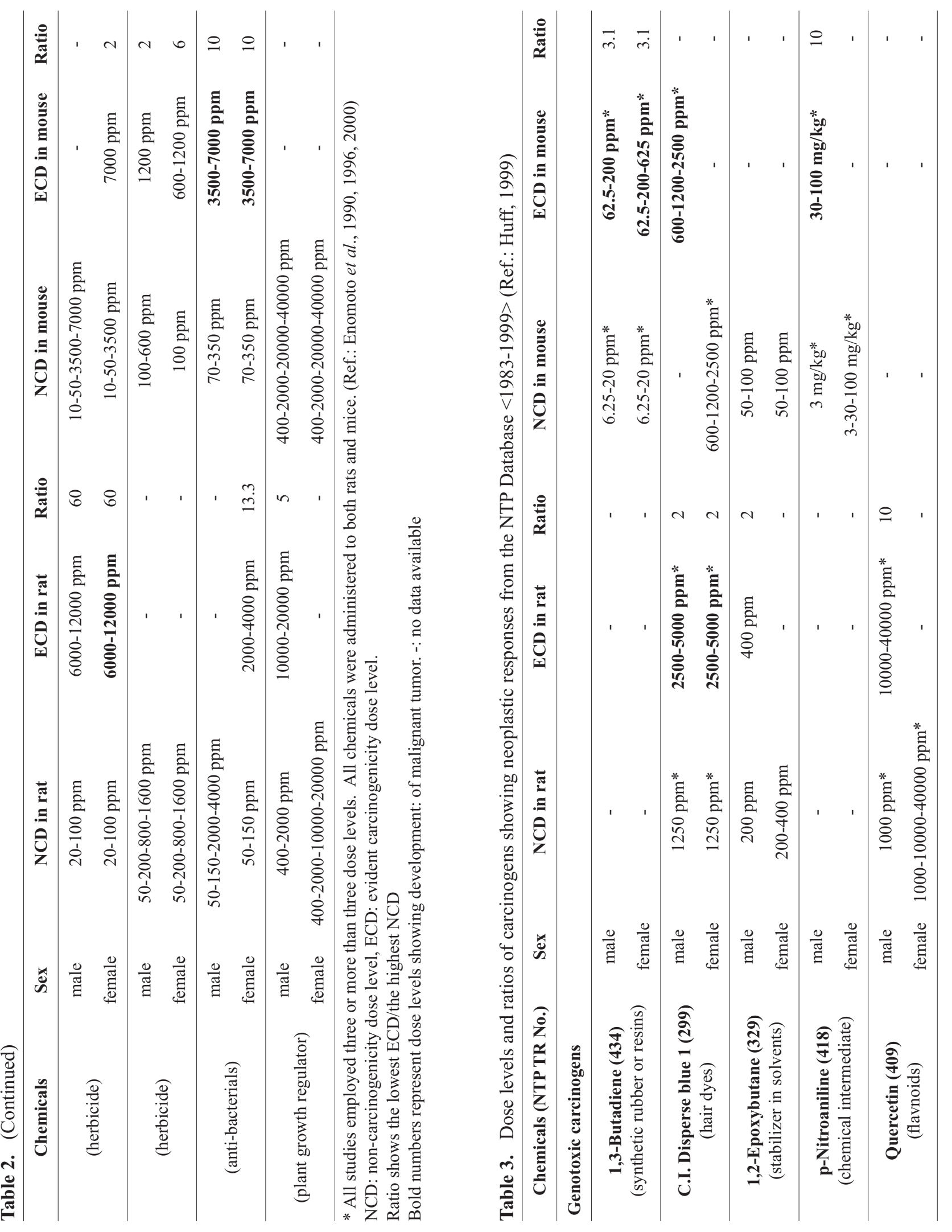

Vol. 33 No. 3 
M. Enomoto et al.

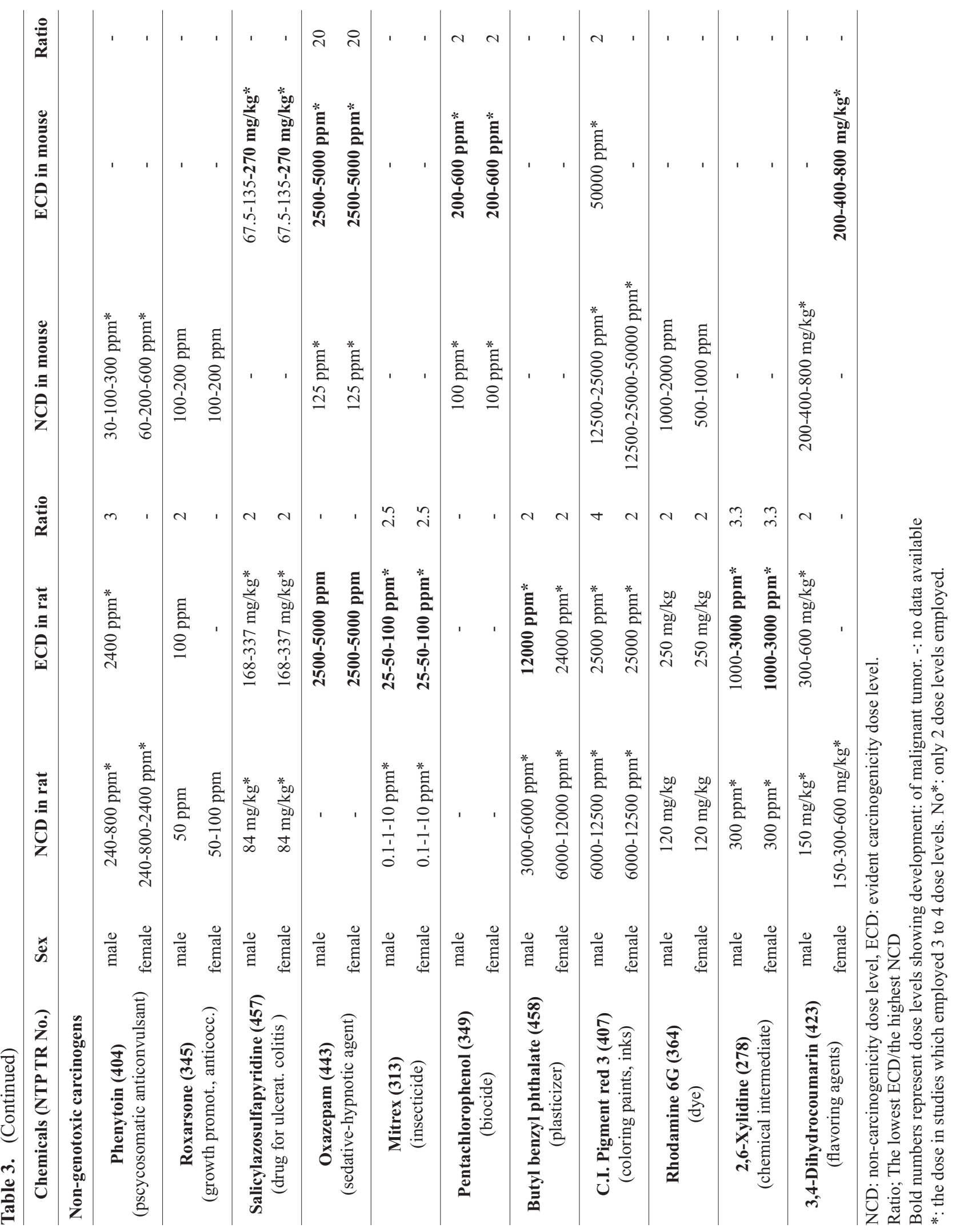

Vol. 33 No. 3 
Air pollution and tobacco smoking

emission sources (Cupitt et al., 1994).

Concern also focused on the contribution of emissions of carcinogenic polycyclic aromatic hydrocarbons (PAH) from cooking sources to fatal atmospheric PAH concentrations on health effects (Mumford et al., 1987; Li et al., 2003). Research on biological mechanisms for health effect of particulates have revealed a variety of influences on respiratory diseases such as asthma, chronic obstructive pulmonary disease (COPD), as well as lung cancer, cardiovascular disease, pregnancy and retarded child growth (Lippmann et al., 2003; Moyer et al., 2002; Suwa et al., 2002; Liu et al., 2003).

Epidemiologic data must be analyzed carefully using appropriate statistical and commonsense approaches. However, the validity of such data must be taken in account. Additional work remains to be done to fully understand the implications of available epidemiologic evidence for a cancer-dose response in humans. For more precise estimates of the risks of low-level exposure, a better understanding of the biological mechanisms and more comprehensive knowledge of the dose-response relationships for various types of biological effects are needed (Stavric, 1994; Gold et al., 1998). In the interim, to take into account the reduced risk of chemicals at low doses and low dose rates, a linear-quadratic function is more appropriate than a simple linear function, for estimating the overall risks of late somatic and genetic effects, under conditions of whole-body, low-level exposure.

The high incidence and often unpredictable prevalence of naturally occurring tumors in aged rodents makes lowdose extrapolations difficult in classical life-time bioassays using animal models (Enomoto et al., 1990). Therefore, the importance of a sufficiently large historical control data base can not be overemphasized for meaningful evaluation of results (Kirsch-Volders et al., 2000).

Our confidence in predicting the likelihood of true risks will inevitably be poor for uncommon hazards due to false/negative results which must be rarer than the risk itself. Since most controversial environmental hazards are infrequent, this poses a dilemma for risk management.

State-of-art research is the first priority, "better science for better decisions". Therefore, risk assessment should encompass the evaluation of all available evidence. The argument for or against a threshold hypothesis must be based on theoretical as well as empirical evidence using commonsense for risk assessments. Conversely, regulatory responsibility may focus on chemicals showing the lower ratio between possible low level carcinogenicity within the control range, and the actual human exposure level, rather than assumptions at highly exaggerated estimates (Stöhrer, 1993).
The primary aim of medical and toxicological research is to define real risks to human health, rather than emphasizing the avoidance of tobacco smoking, pesticides or food additives, as often reported sensationally in the media. Cases of human liver cancer caused by man-made chemicals are extremely rare such as thorotrast, oral contraceptives and vinyl chloride. Carbon tetrachloride is a hepatocarcinogen, which induce hepatic tumors in high incidence in experimental animals even by inhalation. Like the American Conference of Governmental Industrial Hygienists (ACGIH) in the USA (1984), Japan Society for Occupational Health (1991) established the safe dose of carbon tetrachloride to be below 5 ppm, which is one fifth of the dose causing hepatocellular adenoma in $\mathrm{B} 6 \mathrm{C}_{3} \mathrm{~F}_{1}$ mouse. However, there are no reported human cases of hepatic carcinomas following exposure of carbon tetrachloride to date. It must be emphasized that no clear evidence exists for pesticide induced human hepatic cancers worldwide for the past fifty years excluding accidental overexposure or suicide.

Clinical experts on liver diseases in Japan consider the hepatitis virus to be the major cause for liver cancer in humans. The remainder, less than 5 to $10 \%$ of all liver cancers, arise from the consumption of alcoholic beverages. Since alcoholic beverages contain relatively high amount of urethane, from $100 \mathrm{ppb}$ to $20 \mathrm{ppm}$ in brandy (Zimmerli and Schlatter, 1991), there may be a relationship to induction of cancers in the human liver and upper alimental tracts, such as the esophagus and oral cavity. Evaluation of human liver biopsy specimens were conducted for over 30 years with a special attention given to the possibly of exposure to numerous agents, such as hormones. Results have revealed practically no evidence that pesticides-or food-additives induced hepatic cancers (Sugimoto et al.,1982; Enomoto, 1985; Enomoto, 2000).

\section{Evaluation of inhalation studies Comments on tobacco-smoke carcinogenesis}

Exposure to toxicants via inhalation is a consequence in all phases of human activity. The actual doses delivered to human or animal lungs are determined from the ambient concentration of the chemical compounds in the air and technically complicated experimental design of inhalation studies. Extensive progress in rodent bioassays has been accomplished in the past half century at several facilities including Oak Ridge National Laboratory (Oak Ridge, Tenn., USA) CIIT and NIEHS (Research Triangle Park, NC., USA), NCI, NIH (Bethesda, Md., USA) Fraunhofer ITEM (Hannover, Germany) and the Biosafety Research Center, JISHA (Hadano, Japan). 
At present, toxicologists are devoting at great deal attention to the carcinogenic role of particulate air pollution, particularly inhalation studies on diesel exhausts or other particulate matter (Albert et al., 1986; Kuwabara et al., 1986; Mohr and Dungworth, 1988; HERP, 1987; Nozaki, 1988; Woodruff et al., 1998). Significant and promising fruits of recent exploratory studies on a variety of particulate matter hazards, including health effects of the smallest and potentially most toxic ambient particles and ultrafine particles are worth mentioning (Brown et al., 2001; Ghio et al., 2004; Ogami et al., 2007; Roller, 2007).

Among these studies the mechanistic evaluation of PM-induced oxidative stress performed by Xia et al. (2004) has encouraged research on ultrafine particulate toxicity. Another interesting finding was that Kanisawa (1982) demonstrated the possibility of lung cancer induction by oral treatment with nitrofuran in mice. As for human lungs, characterization of particulate matter in smog from autopsy lung samples by Hunt et al. (2003) provided evidence for the toxicological effects of severe PM exposure to smog with evidence of ultrafine carboneaceous and metallic PM.

Since discussion of data obtained by inhalation in animals is outside the scope of this review, the attention will be focused on a critical review of data that influence respiratory carcinogenesis of tobacco smoking.

The portal of entry of inspired air is the nasopharyngeal structure and includes the nasal turbinates, epiglottis, glottis, pharynx and larynx which remove larger air particles through impaction in the nasal turbinates plus filtration by nasal hairs. These structures condition the incoming air and remove the highest concentrations of chemicals before they can enter the lungs. As would be expected from the fact that the nasopharyngeal cavity can remove $50 \%$ or more of inhaled toxicants, individuals who mouth breath when excited or tobacco smokers are less protected without the filtering action of the nasopharynx.

It is evident that exposure levels to carcinogenic agents including aromatic hydrocarbons in particulate matter exceed their very low natural occurrence in the smoke of dried tobacco leaves and lack clear evidence of carcinogenicity in animal studies (Coggins, 1998). A similar lack of evidence in animal studies is suggested in the IARC monograph (IARC, 1990).

Extremely high exposure to cigarette smoke at 250 $\mathrm{mg}$ total particulate matter $/ \mathrm{m}^{3}$ (Hutt et al., 2005; Hahn et al., 2007) or over $1 \mathrm{mg}$ levels per kg body weight in animals which contained benzo (a) pyrene or carcinogenic nitroso-compounds and caused respiratory and other tumors in number of past studies (Hoffmann and Hecht, 1985; IARC, 1990; Walaszek et al., 2007), led us to wonder about this relevance to human carcinogenicity. Calculation of the amount of cigarette exposure to animals conducted in whole body exposure chambers, at a level of $250 \mathrm{mg}$ particulate matter $/ \mathrm{m}^{3}$ for $6 \mathrm{hr} /$ day, required a total of, at minimum, 2,500 cigarettes/day. The amount of tobacco smoke was determined based on a rate of 8 puffs per cigarette per minute with an approximate content of $2.5 \mathrm{mg}$ particulate matter (a cigarette containing $20 \mathrm{mg}$ tar) in a volume of $35 \mathrm{ml}$ of air per puff (Nozaki and Kawai, 1978). Therefore, it would be expected that the mean body weight of such exposed mice would be more than $10 \%$ lower than control animals under such heavily contaminated atmospheric conditions (Hutt et al., 2005), in addition to the increased CO level in the inhaled air.

\section{Toxicological and medical approach to prevention of air pollutants}

Table 4 shows a list of several main chemical carcinogens revealing relatively high exposure to humans throughout normal life. They were compiled from a comprehensive risk assessment and management program for prevention of chemical hazards. Gold et al. (1998) have presented, human exposure/rodent potency (HERP) index for ranking possible carcinogenic hazards from exposure data, daily human exposure and carcinogenic doses from long term animal studies. Since the first five chemicals are known to be the major components of air pollution, further detailed examination of their exposure levels as well as the analyses of the particulate matter should be conducted routinely, in industrialized areas. As for urethane and aflatoxin $\mathrm{B}_{1}$; two major food-born carcinogens, investigation of the dose-response relationship between intake of both chemicals and disorders of the alimentary tract can be of considerable public-health concern, in addition to air pollution in preventive medicine.

The strongest evidence to date that long-term exposure to airborne $\mathrm{PM}_{2.5}$ and products of sulfur oxide air pollution, particularly by fossil fuel combustion may be an important environmental risk factor for cardiopulmonary and lung cancer mortality. Particulate matter from the atmosphere contains nitrogen oxides from car exhaust, rubber particles from tires, debris from brake systems, phosphates from residential and agricultural fertilizers, and dozens of other pollutants including bacterial components (endotoxins). Pollutants may be also released from paving materials. Asphalt is known to contain pitch or oil ash. The top coat is likely to be quite to toxic. 
Air pollution and tobacco smoking

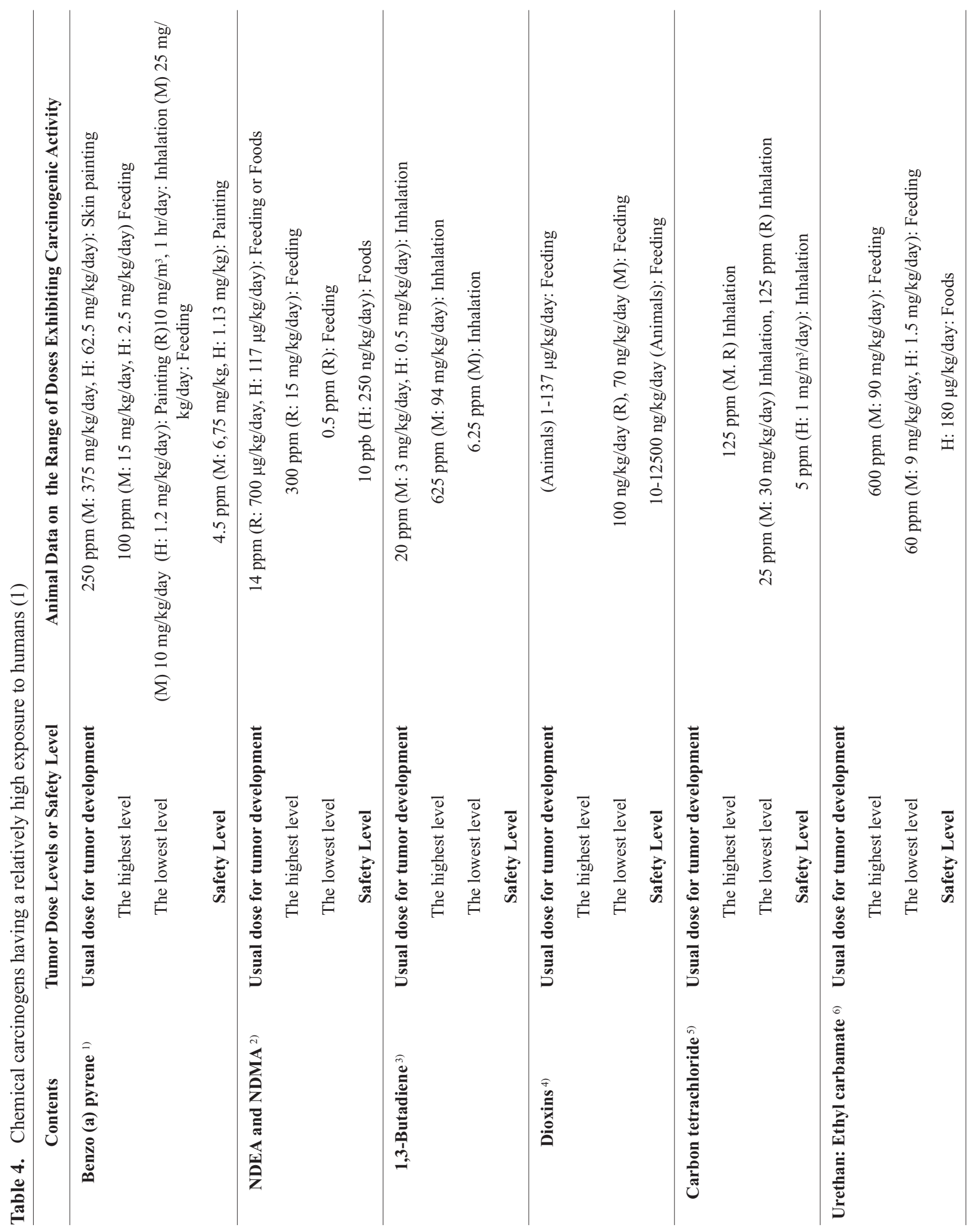

Vol. 33 No. 3 
M. Enomoto et al.

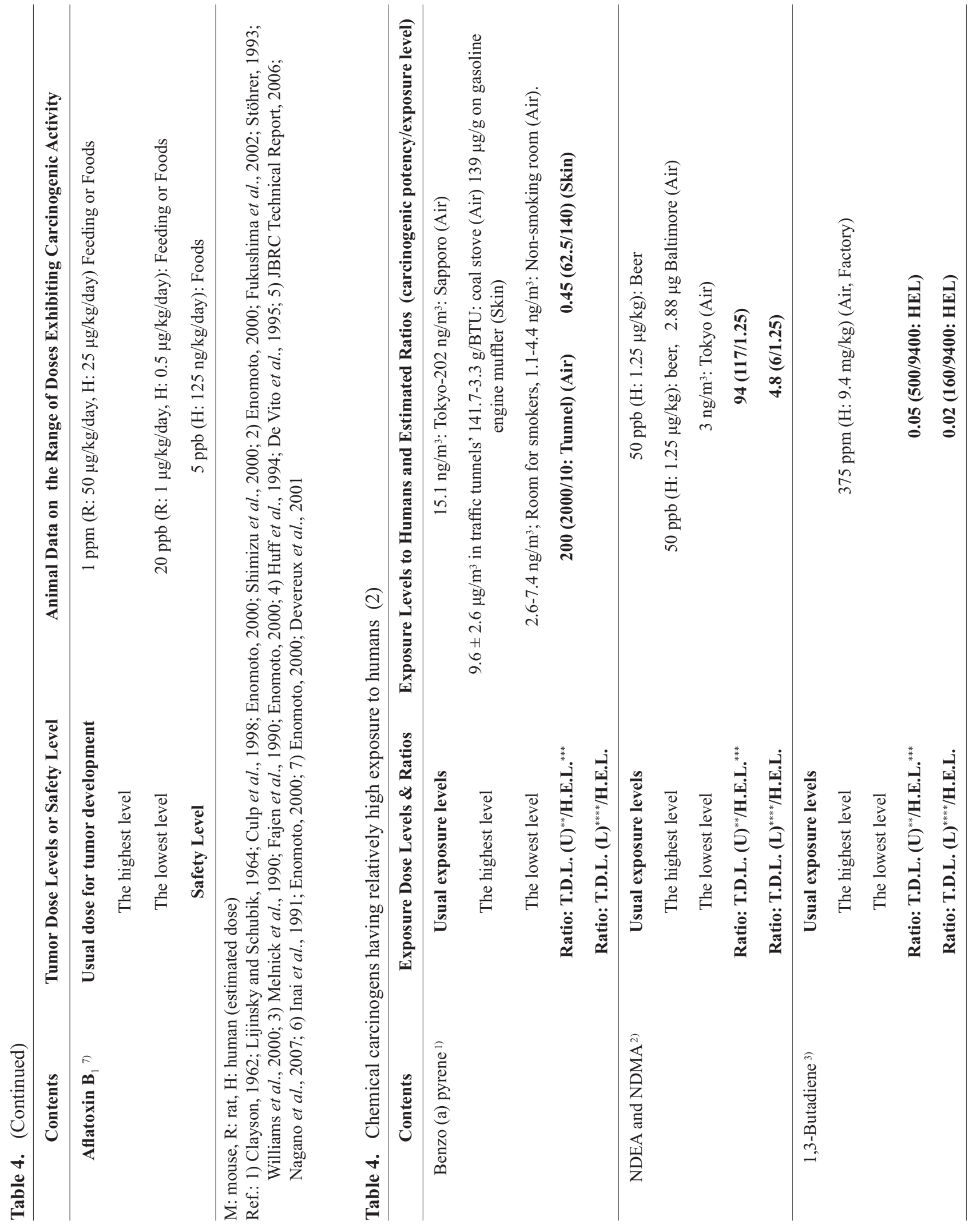

Vol. 33 No. 3 
Air pollution and tobacco smoking
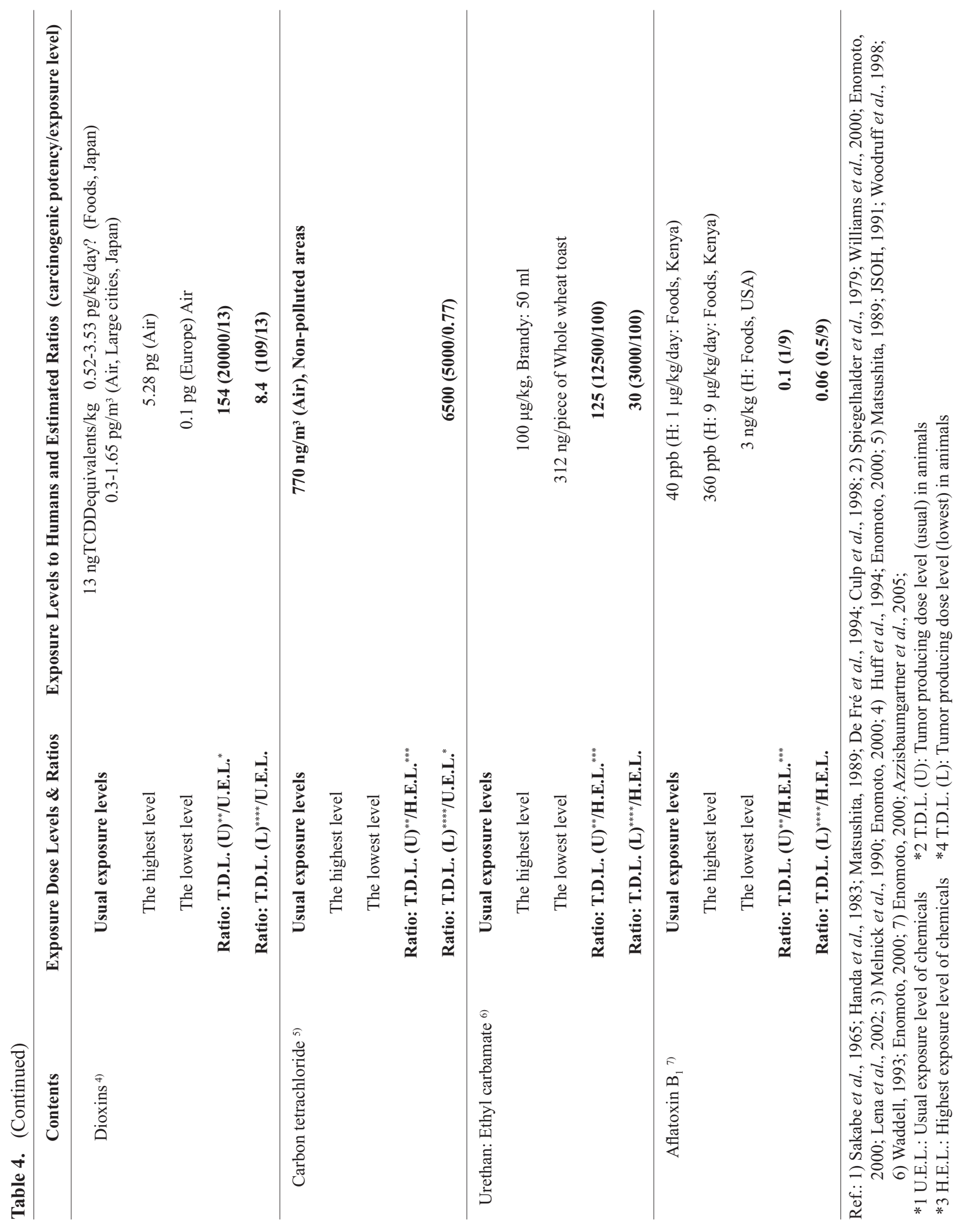

Vol. 33 No. 3 
Unfortunately, there is very little epidemiological evidence of causal agents in polluted air and their influence on respiratory disease in Japan. Rather, attention should focus on reducing automobile emissions and industrial contamination (Lippmann et al., 2003). Automobile exhausts (Falk, 1970; Matsushita, 1985; Albert and Chen, 1986; HERP Program, 1987; Strandell et al., 1994; Caprino and Tonga, 1998) contribute more than a thousand times the concentration of environmental carcinogens than does tobacco smoke (Sakabe et al., 1965; Matsushita, 1989; IARC, 1990; Witschi et al., 1997).

Secondly, the conventional two-year rodent bioassay should focus on genotoxic carcinogens predicted by Ames testing. The qualitative and quantitative analyses of the rodent bioassay, especially with more meaningful data on low-dose effects (Haseman, 2003) will give a clue to their human carcinogenic potential. Non-genotoxic carcinogens will be evaluated by short to subchronic studies in combination with molecular pathology (Boorman et al., 2002; Preston, 2002). The wealth of the database generated from rodent bioassay in the past quarter of a century and the new genetically altered models for carcinogen screening will certainly contribute to more meaningful hazard identification (Maronpot, 1998; Porta et al., 2003, Ohnishi et al., 2007). Future challenges will involve toxicological approaches to integrate recent advances to elucidate the causation and ultimate prevention of human cancer, together with epidemiology studies as suggested by Carbone et al. (2004).

\section{REFERENCES}

Albert, R.E. and Chen, C. (1986): U.S. EPA. diesel studies on inhalation hazards. In: Carcinogenic and Mutagenic Effects of Diesel Engine Exhaust (Ishibashi, N. et al. eds.), pp.411-419, Elsevier Science Publishers B.V., Amsterdam and New York.

American Conference on Governmental Industrial Hygienists (ACGIH). (1984): Threshold limit for chemical substance and physical agents in the work environment with intended changes for 1938-84. pp.42-93, ACGIH, Cincinnati.

Arcos, J.C., Argus, M.F. and Wolf, G. (1968): Introduction. In Chemical Induction of Cancer, pp.3-7, Academic Press, New York.

Ashby, J. and Tennant, R.W. (1991): Definitive relationships among chemical structure, carcinogenicity and mutagenicity for 301 chemicals tested by the U.S. NTP. Mutat. Res., 257, 229-306.

Azziz-Baumgartner, E., Lindblade, K., Gieseker, K., Rogers, H.S., Kieszak, S., Njapau, H., Schleicher, R., McCoy, L.F., Misore, A., DeCock, K., Rubin, C., Slutsker, L. and the Aflatoxin Invest. Groups. (2005): Case-control study of an acute aflatoxicosis outbreak, Kenya, 2004. Environ. Health Perspect., 113, 1779-1783.

Boorman, G.A., Anderson, S.P., Casey, W.M., Brown, R.H., Crosby, L.M., Gottschalk, K., Easton, M., Ni, H. and Morgan, K.T. (2002): Toxicogenomics, drug discovery, and the pathologist. Toxicol. Pathol., 30, 15-27.
Brown, D.M., Wilson, M.R., Mac Nee, W., Stone, V. and Donaldson, K. (2001): Size-dependent proinflammatory effects of ultrafine polystyrene particles: a role for surface area and oxidative stress in the enhanced activity of ultrafines. Toxicol. Applied. Pharmacol. 175, 191-199.

Calabrese, E.J. and Baldwin, L.A. (2003): Hormesis: The doseresponse revolution. Annu. Rev. Toxicol. Pharmacol., 43, 175193.

Caprino, L. and Togna, G.I. (1998): Potential health effects of gasoline and its constituents: a review of current literature (19901997) on toxicological data. Environ. Health Perspect., 106, 115-125.

Carbone, M., Klein, G., Gruber, J. and Wong, M. (2004): Modern criteria to establish human cancer etiology, Meeting report. Cancer Res., 64, 5518-5524.

Churg, A., Brauer, M., Avila-Casado, M.C., Fortoul, T.I. and Wright, J.L. (2003): Chronic exposure to high levels of particulate air pollution and small airway remodeling. Environ. Health Perspect., 111, 714-718.

Clayson, D.B. (1962): Occupational and environmental hazardschemical carcinogenesis in man. In Chemical. Carcinogenesis., pp.13-30. Little, Brown and Company, Boston.

Coggins, C.R.E. (1998): A review of chronic inhalation studies with mainstream cigarette smoke in rats and mice. Toxicol. Pathol., 26, 307-314.

Cook, R. and Calabrese, E.J. (2006): The importance of hormesis to public health. Environ. Health Perspect., 114, 1631-1635.

Culp, S.J., Gaylor, D.W., Sheldon, W.G., Goldstein, L.S. and Beland, F.A. (1998): A comparison of the tumors induced by coal tar and benzo (a) pyrene in a 2 -year bioassay. Carcinogenesis, 19, 117-124.

Cupitt, L. and Fitz-Simmons, T.R. (1988): The integrated air cancer project: Overview and Boise survey results. In: Proceedings of the 1988 EPA/AWMA International Symposium on measurement of toxic and related air pollutants, pp.885-889, VIP10. EPA 600/9-88-015, NTIS PB90-225863. PA-Air and Waste Management Association, Pittsburgh.

Cupitt, L.T., Glen, W.G. and Lewtas, J. (1994): Exposure and risk from ambient particle-bound pollution in an airshed dominated by residential wood combustion and mobile sources. Environ. Health Perspect., 102 (Suppl. 4), 75-84.

Dedrick, R.L. and Morrison, P.F. (1992): Carcinogenic potency of alkylating agents in rodents and humans. Cancer Res., 52, 24642467.

De Fré, R., Bruynseraede, P. and Kretzschmar, J.G. (1994): Air pollution measurements in traffic tunnels. Environ. Health Perspect., 102 (Suppl. 4), 31-37.

Devereux, T.R., Stern, M.C. and Flake, G.P. (2001): CTNNB1 mutations and $\beta$-catenin protein accumulation in human hepatocellular carcinomas associated with high exposure to aflatoxin $\mathrm{B}_{1}$. Mol. Carcinog., 31, 68-73.

DeVito, M.J., Birnbaum, L.S., Farland, W.H. and Gasiewicz, T.A. (1995): Comparisons of estimated human body burdens of dioxinlike chemicals and TCDD body burdens in experimentally exposed animals. Environ. Health Perspect., 103, 820-831.

Enomoto, M. (1985): How does Japan differentiate hyperplasia form neoplasia? Toxicol. Pathol., 13, 110-118.

Enomoto, M., Kobayashi, K. and Inoue, H. (1990): Significance of naturally-occurring tumors in evaluating the carcinogenicity of a test compound: A review and an improved carcinogenicity bioassay for chemicals. J. Toxicol. Pathol., 3, 1-17.

Enomoto, M., Inoue, H., Yamamoto, T., Kobayashi, K., Hirouchi, 
Air pollution and tobacco smoking

Y., Iwata, H., Yamakawa, S., Kobayashi, K. and Sugiyama, S. (1996): Interpretation of bioassay results-Species, sex, and tumor-site specific carcinogenic effects in long-term studies in rats and mice-. J. Toxicol. Pathol., 9, 1-12.

Enomoto, M. (2000): A search for chemical agents causing human cancer -Lessons learned from rodent carcinogenicity studies-. J. Toxicol. Sci., 25, 381-392.

Fajen, J.M., Roberts, D.R., Ungers, L.J. and Krishnan E.R. (1990): Occupational exposure of workers to 1,3-Butadiene. Environ. Health Perspect., 86, 11-18.

Falk, L.H. (1970): Chemical definitions of inhalation hazards. In: Inhalation Carcinogenesis (Hanna, M.G., Nettesheim, P. and Gilbert, J.R. eds.), pp.389-412, NTIS, US Dept., Commerce, Springfield, Va.

Fraser, P. (1991): Reducing the risk. In: Cancer Risk after Medical Treatment (Coleman, M.P., ed.), pp.153-173, Oxford University Press, Oxford.

Fukushima, S., Wanibuchi, H., Morimura, K., Wei, M., Nakae, D., Konishi, Y., Tsuda, H., Uehara, N., Imaida, K., Shirai, T., Tatematsu, M., Tsukamoto, T., Hirose, M., Furukawa, F., Wakabasyshi, K. and Totsuka, Y. (2002): Lack of a doseresponse for carcinogenicity in the rat liver with low doses of 2amino-3, 8-dimethylimidazo [4, 5- $f$ quinoxaline or N-nitrosodiethylamine. Jpn. J. Cancer Res., 93, 1076-1082.

Fung, V.A., Barrett, J.C. and Huff, J. (1995): The carcinogenesis bioassay in perspective: Application in identifying human cancer hazards. Environ. Health. Perspect, 103, 680-683.

Ghio, A.J., Churg, A. and Roggli, V.L. (2004): Ferruginous bodies: Implications in the mechanism of fiber and particle toxicity. Toxicol. Pathol. 32, 643-649.

Gold, L.S., Slone, T.H. and Ames, B.N. (1998): What do animal cancer tests tell us about human cancer risk?: Overview of analyses of the carcinogenic potency database. Drug Metab. Rev., 30, 359-404.

Hahn, F.F., Gigliotti, A.P., Hutt, J.A., March, T.H. and Mauderly, J.L. (2007): A review of the histopathology of cigarette smokeinduced lung cancer in rats and mice. Intern. J. Toxicol., 26, 307313.

Handa, T., Yamauchi, T., Ohnishi, M., Hisamatsu, Y. and Ishii, T. (1983): Detection and average content levels of carcinogenic and mutagenic compounds from the particulates on diesel and gasoline engine mufflers. Environ. Internat., 9, 335-341.

Haseman, J.K. and Seilkop, S.K. (1992): An examination of the association between maximum-tolerated dose and carcinogenicity in 326 long-term studies in rats and mice. Fundam. Appl. Toxicol., 19, 207-213.

Haseman, J.K. (2003): An alternative perspective: A critical evaluation of the Waddell threshold extrapolation model in chemical carcinogenesis. Toxicol. Pathol., 31, 468-470.

Hengstler, J.G., Bogdanffy, M.S., Bolt, H.M. and Oesch, F. (2003): Challenging dogma: thresholds for genotoxic carcinogens? The case of vinyl acetate. Annu. Rev. Pharmacol. Toxicol., 43, 485520.

HERP Program (1987): Health Effects of Diesel Exhaust. Subcommittee of the Inhalation Studies, HERP, pp.5-417, Japan Automobile Assoc., Tokyo.

Hoffmann, D. and Hecht, S.S. (1985): Nicotine-derived N-nitrosamines and tobacco-related cancer: Current status and future directions. Cancer Res., 45, 935-944.

Hueper, W.C. and Conway, W.D. (1964): Carcinogenicity of aromatic hydrocarbons. In Chemical Carcinogenesis and Cancers, pp.200-210, Charles C. Thomas Publ., Springfield.
Huff, J.E., McConnell, E.E., Haseman, J.K., Boorman, G.A., Esutis, S.L., Schwets, B.A., Rao, G.N., Jameson, C.W., Hart, L.G. and Rall, D.P. (1988): Carcinogenesis studies: Results of 398 experiments on 104 chemicals from the U. S. National Toxicology Program. Ann. N.Y. Acad. Sci., 534, 1-30.

Huff, J.E., Lucier, G. and Tritsoher, A. (1994): Carcinogenicity of TCDD: Experimental, mechanistic and epidemiologic evidence. Annu. Rev. Pharmacol. Toxicol., 34, 343-372

Huff, J.E. (1999): Value, validity, and historical development of carcinogenesis studies for predicting and confirming carcinogenic risks to humans. In: Carcinogenicity. Testing, predicting and interpreting chemical effects (Kitchin, K.T. ed.), pp.21-115, Marcel Dekker, Inc., N.Y. and Basel.

Hunt, A., Abraham, J.L., Judson, B. and Berry, C.L. (2003): Toxicologic and epidemiologic clues from the characterization of the 1952 London smog fine particulate matter in archival autopsy lung tissues. Environ. Health Perspect., 111, 1209-1204,

Hutt, J.A., Vuillemenot, B.R., Barr, E.B., Grimes, M.J., Hahn, F.F., Hobbs, C.H., March, T.H., Gigliotti, A.P., Seilkop, S.K., Finch, G.L., Mauderly, J.L. and Belinsky, S.A. (2005): Life-span inhalation exposure to mainstream cigarette smoke induces lung cancer in $\mathrm{B} 6 \mathrm{C} 3 \mathrm{~F} 1$ mice through genetic and epigenetic pathways. Carcinogenesis, 26, 1999-2009.

Inai, K., Arihiro, K., Takeshima, Y., Yonehara, S., Tachiyama, Y., Khatun, N. and Nishisaka, T. (1991): Quantitative risk assessment of carcinogenicity of urethane (ethyl carbamate) on the basis of long-term oral administration to B6C3F1 mice. Jpn. J. Caner Res., 82, 380-385.

International Agency for Research on Cancer (IARC). (1990): Tobacco Smoking In IARC Monographs on the evaluation of the carcinogenic risk of chemicals to humans, 38, pp.69-182, IARC, Lyon, France.

Japan Bioassay Research Center Technical Report. (2006): Abstract of carcinogenicity study on carbon tetrachloride in rats and mice by inhalation. In 20 Years Ayumi of JBRC, pp.174, JISHA., Tokyo.

Japan Society for Occupational Health. (1991): Documentation of the occupational exposure limit value for carbon tetrachloride and chloroform. Jpn. J. Ind. Health, 33, 31-312.

Kanisawa, M. (1982): Developmental steps in experimentally induced adenocarcinoma of the lun. In: Morphogenesis of Lung Cancer, Vol.II (ed. Shimosato, Y.U. and Melamed, M.R.), Florida, CRC Press Inc., pp.181-204.

Kirsch-Volders, M., Aardema, M. and Elhajouji, A. (2000): Concepts of threshold in mutagenesis and carcinogenesis. Mutat. Res., 464, 3-11.

Kitagawa, M. (1965): Autopsy study of lung cancer with special reference to scar cancer. Acta Pathol. Japon. 15, 199-222

Kundsen, Ib. (1999): Temporal equivalence between test species and humans: General toxicity issues. Regul. Toxicol. Pharmacol., 30, S42-47.

Kuwabara, N., Takagi, Y., Kitamura, N., Homma, S., Uegusa, T., Wakabayashi, K., Aze, Y. and Kato, T. (1987): Histopathological examination. In: Health Effects of Diesel Exhaust Substances (Inhalation Study Committ. ed.), pp.195-236., HERP Study Group, Japan. Automob. Inst., Tokyo.

Lena, T.S., Ochieng, V., Carter, M., Holguin-Veras, J. and Kinney, P.L. (2002): Elemental carbon and PM2.5 levels in an urban community heavily impacted by truck traffic. Environ. Health Perspect., 110, 1009-1015.

Lewis, D.F.V., Ioannides, C. and Parke, D.V. (1998): Cytochromes P450 and species differences in xenobiotic metabolism and acti- 


\section{Enomoto et al.}

vation of carcinogen. Environ. Health Perspect., 106, 633-641.

Lewtas, J., Nesnow, S. and Albert, R.A. (1983): A comparative potency method for cancer risk assessment: classification of the rationale, theoretical basis, and application to diesel emissions. Risk Anal., 3, 33-137.

Lewtas, J. (1993): Complex mixtures of air pollutants: characterizing the cancer risk of polycyclic organic matter. Environ. Health Perspect., 100, 211-218.

Li, C.-T., Lin, Y.-C., Lee, W.-J. and Tsai, P.-J. (2003): Emission of polycyclic aromatic hydrocarbons and their carcinogenic potencies from cooking sources to the urban atmosphere. Environ. Heslth Perspect. 111, 483-487.

Lijinsky, W. and Schubik, B. (1964): Dose response study of carcinogenesis in rats by benzo (a) pyrene. Cancer Res., 24, 152158.

Lippmann, M., Frampton, M., Schwatz, J., Dockery, D., Schlesinger, R., Koutrakis, P., Froines, J., Nel, A., Finkelstein, J., Godleski, J., Kaufman, J., Koenig, J., Larson, T., Luchtel, D., Liu, J-J.S., Oberdoerster, G., Peters, A., Sarnat, J., Sioutas, C., Suh, H., Sullivan, J., Uterll, M., Wichmann, E. and Zelikoff, J. (2003): The U.S. Environmental Protection Agency particulate matter health effects research centers program: A midcourse report of status, progress and plans. Environ. Health Perspect., 111, 1074-1092.

Liu, S., Kewski, D., Shi, Y., Chen, Y. and Burnett, R.T. (2003): Association between gaseous ambient air pollutants and adverse pregnancy outcomes in Vancouver, Canada. Environ. Health Perspect., 111, 1773-1778.

Maronpot, R.R. (1985): Consideration in the evaluation and interpretation of long-term animal bioassays for carcinogenicity. In* Handbook of Carcinogen Testing (Milman, H.A. and Weisburger, E.K. eds.), pp.372-382, Noyes Publication, Auk Ridge, N.J.

Maronpot, R.R. (1998): The potential of genetically altered mice as animal models for carcinogen identification, Commentary. Toxicol. Pathol. 26, 579-581.

Mastrangelo, G., Fadda, E. and Marzia, V. (1996): Polycyclic aromatic hydrocarbons and cancer in man., Environ. Health Perspect., 104, 1166-1170.

Matsui, A. (1960): A supplementary report of studies on histo-pathological examination and clinical symptoms in the diagnosis and therapy of pulmonary cancer. J. Japan. Pathol. Assoc., 49, 837864.

Matsushita, H. (1985): Analysis of diesel car exhaust gas. In: Review of Air Pollutants -Diesel exhaust-, Japan Environmental Agency, pp.82-117, Nihon Kagakugijutsu Jouhou Center, Tokyo.

Matsushita, H. (1989): Air pollution. In: Handbook of Modern Pathology, Exogenous Factors, pp.15-42, Nakayama Publ., Tokyo.

Melnick, R.L., Huff, J., Chou, B.J. and Miller, R.A. (1990): Carcinogenicity of 1, 3-butadiene in C57BL/6 X C3 $\mathrm{HF}_{1}$ mice at low exposure concentrations. Cancer Res., 50, 6592-6599.

Menzel, D.B. and Amdur, M.O. (1996): Toxic responses of the respiratory system. In: Casarett and Doull's Toxicology; The Basic Science of Toxicology (Klaasssen, C.D., Amdur, M.O. and Doull, J. eds.), pp.330-358, McGraw-Hill, N.Y.

Mohr, U. and Dungworth, D.J. (1988): Relevance to humans of experimentally induced pulmonary tumors in rats and hamsters. In: Inhalation Toxicology; the design and interpretation of inhalation studies and their use in risk assessment (Dungworth, D., Kimmerle, G. and Lewkowski, J., eds.), pp.209-232, SpringerVerlag, N.Y.
Mohr, U., Ernst, H., Roller, M. and Pott, F. (2006): Pulmonary tumor types induced in Wistar rats of the so-called "19-dust study". Exp. Toxicol. Pathol., 58, 13-20.

Moyer, C.F., Kodavanti, U.P., Haseman, J.K., Costa, S.L. and Nyska, A. (2002): Systemic vascular disease in male B6C3F1 mice exposed to particulate matter by inhalation: Studies conducted by the National Toxicology Program. Toxicol. Pathol., 30, 427-434.

Mumford, J.L., He, X.Z., Chapmann, R.S., Cao, S.R., Harris, D.B., Li, X.M., Xian, Y., Jiang, W., Xu, C.W., Chuang, J.C., Wilson, W.E. and Cook, M. (1987): Lung cancer and indoor air pollution in Xuan Wei. China., Science, 235, 217-220.

Nagano, K., Umeda, Y., Saito, M., Nishizawa, T., Ikawa, N., Arito, H., Yamamoto, S. and Fukushima, S. (2007): Thirteenweek inhalation toxicity of carbon tetrachloride in rats and mice. J. Occup. Health, 49, 249-259.

Nozaki, K. (1966): Method or studies on inhaled particles in human respiratory system and retention of lead fume. Ind. Health, $\mathbf{4}$, 118-128.

Nozaki, K. and Kawai, K. (1978): Physicochemical study on tobacco smoking and lung cancer. In: Conference on health effects of tobacco smoking, June 23, Tokyo, Bulletin of The Japan. Tobacco \& Salt Corp., Tokyo.

Nozaki, K. (1988): Health effect of studded tire-generated dustsStudy on rats exposed to dusts for 78 weeks. In: Preventive measures for particulate matters generated by studded tire-Subcommittee of human hazard-., pp.1-17, Environ. Agency, Tokyo.

O'Connor, P.J., Manning, F.C.R. and Gordon, A.R. (2000): DNA repair: Kinetics and thresholds. Toxicol. Pathol., 28, 375-381.

Ogami, A., Morimoto, Y., Myojo, T., Oyabu, T., Murakami, M., Nishi, K., Kadoya, C. and Tanaka, I. (2007): Histopathological changes in rat lung following intratracheal instillation of silicon carbide whiskers and potassium octatitanate whiskers. Inhal. Toxicol., 19, 753-758.

Ohnishi, T., Fukamachi, K., Ohshima, Y., Jiegou, X., Umeda, S., Iiko, M., Takasuka, N., Naito, A., Fujita, K., Matsuoka, Y., Izumi, K. and Tsuda, H. (2007): Possible application of human c-Ha-ras proto-oncogene transgenic rats in a medium-term bioassay model for carcinogens. Toxicol. Pathol., 35, 436-443.

Porta, M., Ayude, D., Alguacil, J. and Jariod, M. (2003): Exploring environmental causes of altered ras effects: Fragmentation plus integration? Mol. Carcinog., 36, 45-52.

Preston, J. (2002): Quantitation of molecular endpoints for the doseresponse component of cancer risk assessment. Toxicol. Pathol. 30, $112-116$.

Roe, F.J.C. (1972): Actuarial methods in the evaluation of data from long term animal experiments. In: Inhalation Carcinogenesis (Hanna, M.G., Nettesheim, P. and Gilbert, J.R. eds.), pp.389412, NTIS, US Dept., Commerce, Springfield, Va.

Roller, M. (2007): Differences between the data bases, statistical analyses, and interpretations of lung tumors of the 19-dust studyTwo controversial views. Exp. Toxicol. Pathol., 58, 393-405.

Sakabe, H., Matsushita, H., Hayhashi, H., Nozaki, K. and Suzuki, Y. (1965): Mineral components and 3, 4-benzpyrene in air pollutants of Tokyo. Ind. Health, 3, 126-139.

Schwatz, J., Laden, F. and Zanobetti, A. (2002): The concentration-response relation between $\mathrm{PM}_{2.5}$ and daily deaths. Environ. Health Perspect., 110, 1025-1029.

Shimizu, Y., Nakatsuru, Y., Ichinose, M., Takahashi, Y., Kume, H., Mimura, J., Fujii-Kuriyama, Y. and Ishikawa, T. (2000): Benzo (a) pyrene carcinogenicity is lost in mice lacking the aryl hydrocarbon receptor. PNAS, 97, 779-782. 
Air pollution and tobacco smoking

Soffritti, M., Belpoggi, F., Minardi, F. and Maltoni, C. (2002): Ramazzini foundation cancer program. History and major projects, life-span carcinogenicity bioassay design, chemicals studied, and results. Ann. N.Y. Acad. Sci., 982, 26-45.

Spiegelhalder, B., Eisenbrand, G. and Preussman, R. (1979): Contamination of beer with trace quantities of N-nitrosodimethylamine. Food Cosmet. Toxicol., 17, 29-31

Stavric, B. (1994): Biological significance of trace levels of mutagenic heterocyclic aromatic amines in human diet: A critical review. Fd. Chem. Toxic., 32, 977-994.

Stöhrer, G. (1993): Correspondence re: R. Peto, et al., (1991): Effects of 4080 rats of chronic ingestion of N-Nitrosodiethylamine or N-Nitrosodimethylamine: A detailed dose-response study. Cancer Res., 51, 6415-6451, and Crump, K.S. et al. (1976): Fundamental carcinogenic processes and their implications for low dose risk assessment. Cancer Res., 36, 2973-2979.

Strandell, M., Ekrissoson, S., Alsberg, T., Westerholm, R., Winquist, L. and Rannug, U. (1994): Chemical analysis and biological testing of a polar fraction of ambient air, diesel engine, and gasoline engine particulate extracts. Environ. Health Perspect., 102 (Suppl. 4), 85-92.

Sugimoto, M., Ueno, K., Sato, G., Yamamoto, J., Sato, R., Toyokawa, H., Fukuda, M., Mabuchi, M., Enomoto, M., Endo, R., Ishizuka, A., Kuwayama, K. and Yamane, M. (1982): Clinico-pathological studies on 128 cases of primary liver carcinoma. Med. J. Mutual Aid Assoc., 31, 1-13.

Suwa, T., Hogg, J.C., Quinlan, K.B., Ogami, A., Vincent, R. and van Eeden, S.F. (2002): Particulate air pollution induces progression of atherosclerosis. J. Am. Coll. Cardiol., 39, 935-942.

Takemoto, K., Namie, K. and Ohtani, H. (1968): Relationship of deposits of particulate matters and proliferation of the bronchial epithelium in dog lungs to air pollution. Igaku-no-ayumi, $\mathbf{6 5}$, 89-93.

Tennant, R.W. (1993): A perspective on nonmutagenic mechanisms in carcinogenesis. Environ. Health Perspect., 101 (Suppl. 3), 231-236.

Valberg, P.A. and Crouch, E.A. (1999): Meta-analysis of rat lung tumors from lifetime inhalation of diesel exhaust. Environ.
Health Perspect, 107, 693-699.

Waddell, W.J. (1993): Human risk factors to naturally occurring carcinogens: thresholds, inhibitors and inducers. J. Toxicol. Sci., 18, $73-82$

Walaszek, Z., Hanausek, M. and Slaga, T. (2007): The role of skin painting in predicting lung cancer. Internat. J. Toxicol., 26, 345351.

Ward, J.M. (2007): The two-year rodent carcinogenesis bioassayWill it survive? J. Toxicol. Pathol. 20, 13-19.

Weinberg, R.A. (1996): In Racing to the Beginning of the Road: The search for the origin of cancer, pp.21, W.H. Freeman and Company, New York.

Williams, G.M., Iatropoulos, M.J. and Jeffrey, A.M. (2000): Mechanistic basis for nonlinearities and thresholds in rat liver carcinogenesis by the DNA-reactive carcinogens 2-acetylaminofluorene and diethylnitrosamine. Toxicol. Pathol., 28, 388-395.

Williams, G.M., Jeffrey, A.M., Duan, J.D. and Iatropoulos, M.J. (2004): Thresholds in experimental chemical hepatocarcinogenesis. In: Proceedings of the 20th Japan. Soc. Toxicol. Pathol. and the 5th IFSTP, pp.63, February, 15-18, Kobe.

Witschi, H., Espiritu, I., Maronpot, R.R., Pinkerton, K.E., Jones, A.D. (1997): The carcinogenic potential of the gas phase of environmental tobacco smoke. Carcinogen., 18, 2035-2042

Woodruff, T.J., Axelrad, D.A., Caldwell, J., Morello-Frosch, R. and Rosenbaum, A. (1998): Public health implications of 1990 air toxics concentrations across the United States. Environ. Health Perspect., 106, 245-251.

Xia, T., Korge, P., Weiss, J.N., Li, N., Venkatesen, M.I., Sioutas, C. and Nel, A. (2004): Quinones and aromatic chemical compounds in particulate matter induce mitochondrial dysfunction: Implications for ultrafine particle toxicity. Environ. Health Perspect., 112, 1347-1358.

Yamagiwa, K. and Ichikawa, K. (1918): Experimental study of the pathogenesis of carcinoma. J. Cancer Res., 3, 1. (Ref. to (1977) CA Cancer J. Clin., 27, 174-181.)

Zimmerli, B. and Schlatter, J. (1991): Ethyl carbamate: analytical methodology, occurrence, formation, biological activity and risk assessment. Mutat. Res., 259, 325-350. 